\title{
Türk Eğitim Tarihi Dersinin Eğitim Fakültesi Öğrencilerinin Eleştirel Düşünme, Sorgulama ve Sorumluluk Bilinçlerinin Gelişimine Katkısı: Aksaray Üniversitesi Örneği
}

\author{
DOI: 10.26466/opus.733260 \\ * \\ Savaș Karagöz * \\ * Doç.Dr., Aksaray Üniversitesi, Eğitim Fakültesi, Aksaray/Türkiye, \\ E-Posta: savaskaragoz@aksaray.edu.tr O ORCID: 0000-0002-4410-9214
}

Öz

Öğretmenlerin meslek tarihi olarak adlandırlan Türk eğitim tarihi dersi Eğitim Fakülteleri eğitim programında 2006 yılından 2018 yılına kadar genel kültür dersleri içerisinde gösterilmiştir. YÖK tarafından 2018 yılında eğitim fakülteleri programlarında yapılan son değişikle Türk eğitim tarihi dersi meslek bilgisi dersleri arasında yerini almıştır. Türk eğitim tarihi dersi her ne kadar eğitimle ilgili olgu ve olayları kronolojik olarak verse de bu ders aslında öğretmen adaylarına başka becerileri de kazandırmada etkili bir derstir. Bu düşünceyle araştırmada 2018-2019 akademik yılında Aksaray Üniversitesi Eğitim Fakültesi ikinci, üçüncü veya dördüncü sınfföğrencilerinin Türk eğitim tarihi dersine yönelik görüşleri, bakış açıları ve düşünce yapıları incelenmiştir. Bu araştırmada nitel bir araştırma deseni tercih edilmiştir. Veriler içerik analizi tekniği kullanılarak analiz edilmiştir. Veri seti öncelikle okunarak veriler üzerinde notlar alınmış, ardından alınan notlar doğrultusunda ilk önce kod listesi meydana getirilmiştir. Oluşturulan kodların güvenilirliğini să̆lamak amacıyla Miles ve Huberman tarafından tanımlanan formül kullanılmıştır. Belirtilen güvenirlilik formülü doğrultusunda kodlayıcılar arasındaki ortalama güvenirlilik \%90 olarak bulunmuştur. Kodların güvenilirliliği bu şekilde sağlandıktan sonra kodların benzerliklerine göre temalar oluşturulmuştur. Bu temalarm ise, Beceri ve Bilinç Geliştirme (alt temalar: Düşünme Becerilerini Geliştirme, Eleştirel Düşünme Becerisi, Çok Boyutlu Düşünme Becerisi, Bağımsız Düşünme Becerisi, Sorgulama Becerisi Kazandırma, Sorumluluk Bilinci Kazandırma), Eğitimin değeri ve gerekliliğinin farkına varma, Geleceği inşa edebilmek için geçmişten ders çıkarma olduğu görülmüştür.

Anahtar Kelimeler: Türk eğitim tarihi, eleştirel düşünme, sorumluluk bilinci, sorgulama becerisi, 


\title{
Contribution of History of Turkish Education course to the Development of Critical thinking, Sense of Responsibility, Query skill of the Students in the Faculty of Education:A Sample of Aksaray University
}

\begin{abstract}
History of Turkish Education course, a vocational course for teacher candidates, was one of the general knowledge courses of curriculum of colleges of education from 2006 to 2018. Along with the recent update on curriculum of colleges of education by Council of Higher Education in 2018, History of Turkish Education course was in fact organized as one of the vocational courses in the curriculum. Although History of Turkish Education course presents teacher candidates with events and facts related education chronologically, the course is effective on improving other qualities of prospective teachers as well. With this thought in mind, the present study aimed to examine views, opinions and mentalities of sophomore, junior and senior students on History of Turkish Education in college of education at Aksaray University during the 2018-2019 academic year. To achieve this aim, a qualitative design was chosen in the study. The data analysis was done using content analysis technique. Primarily, the dataset was read while taking notes on data; secondarily, the primary code list was created according to these notes. In order to ensure the reliability of the codes, the formula by Miles and Huberman was used. Interrater reliabilty between codes was found to be $90 \%$. After ensuring the reliability this way, themes were created from the primary code list. These themes are Skill and Awareness Development (subthemes: Thinking Skills Development, Critical Thinking Skill Development, Multidimensional Thinking Skill Development, Independent Thinking Skill Development, Query Skill Development, Sense of Responsibility), Realizing the value and necessity of education and Taking Lessons from the Past to Build the Future.
\end{abstract}

Keywords: History of Turkish Education, Critical thinking, Sense of Responsibility, Query skill. 


\section{Giriş}

Sosyal bilimler bünyesi içerisinde yer alan tarihi; geçmişte olan olaylar veya bu olaylar hakkındaki belgelerin verileri olarak tanımlayan Köstüklü (2004), ayrıca tarih biliminin doğuşunda tarihsel olayların, belge ve dokümanların bilimsel bir yöntemle incelenmesinin etkili olduğunu belirtmiştir. Tarih: geçmişteki olayları; yer, zaman ve kişileri göstererek ilgili kaynaklara dayalı olarak sebep-sonuç ilişkisi içerisinde inceleyen bir bilim dalı olarak açıklanır. Köstüklü (2004) yine tarih öğretiminin amaçlarını; öğrencinin geçmişe ilgisini çekme, öğrencinin diğer milletlerin ve kültürel değerlerini tanıması ve anlamasına yardımon olma, geçmişin tecrübesiyle günümüzü daha iyi anlama, eğitim programlarınn diğer alanların çeşitlendirme, özverili ve disiplinli çalışma ile zihni gelişime katkıda bulunma, öğrencileri gelecek için hayata hazır hale getirme ve öğrencinin milli bilinç duygularını inkişafina katkı sağlama olarak sıralamıştır. Benzer şekilde Dinç (2009) Slater (1989) ve Hosbsbawn (1997)' dan aktardığına göre; tarih öğretiminin amaçlarına dikkat çekmiş ve tarih öğretiminin işlevini ön plana alarak, tarihten beklenen ana işlevin, bireylerin kendi kültürel değerlerinin, mahalli ve millet olarak değişim ve gelişimleri de içeren dünyadaki tüm değişim ve gelişmelerin zaman içerisindeki seyrini anlama konusunda insanlara yardımcı olma şeklinde belirtmiştir. Dinç (2009) ayrıca tarihin bir diğer katkısını ise, insanlara sorgulama ve eleştirel düşünmeyi öğreterek; insanları dünyanın mevcut problemleriyle yüzleşmeye hazırlama olarak ifade etmiştir. Bu ifadeyle 21. Yüzyıl becerileri olan eleştirel düşünme, sorumluluk ve sorgulama becerilerine de dikkat çekmiştir.

Eleştirel düşünme, sorumluluk bilinci ve sorgulama becerisi, genellikle bütün eğitim- öğretim kademelerinde kazandırılması gereken önemli özelliklerdendir. Nitekim, bilgi üreten çağdaş bir toplum olmanın temelinde, yeni buluşlar ve keşifler yapan ve sosyal değişimi başlatmak isteyen eleştirel ve yaratıcı düşünme becerilerine sahip eğitimli bireyler yatmaktadır (Orakcı, Durnalı ve Aktan, 2019; Dilekli, 2019). Özellikle sosyal bilimlere ilişkin derslerde eleştirel düşünme "arzu edilen çıktı" olarak kabul edilir (Watson ve Glaser, 1964, s.9). Benzer şekilde, Milli Eğitim Bakanlı̆̆ı'nın 2005 yılında uygulamaya geçirdiği programlarda, "Temel Beceriler" adı altında sekiz temel beceriden birisi olan eleştirel düşünmenin önemi ayrıca vurgulanmaktadır. Bu bağlamda programın öngördüğü gereksinimleri karşılayabilen yetenekli 
öğretmen yetiştirme sorunu karşımıza çıkmaya devam etmektedir. Bu noktada, eğitim fakülteleri hayati derecede önemli bir rol oynamaktadır. Paul, Elder ve Bartell (1997) eleştirel düşünebilen ve problem çözme becerisine sahip öğrenciler yetiştirebilmek için bu becerilere sahip öğretmenlere olan gereksinimleri vurgulayarak eğitim fakültelerinin önemini yansitmaktadır.

Tarih bilimiyle yakından ilişkili olan Eğitim Tarihi Bilimi' de hem bağımsız bir bilim olması hem de bireylere tarih bilincinin kazandırılması açısından tarih bilimine katkı sağlamaktadır. Bu yönüyle Eğitim tarihi ve Türk eğitim tarihi konularının öğretmen adaylarına 21. Yüzyılın istediği becerileri kazandırmada ve 22. Yüzyılın istemiş olduğu bireyleri hazırlamada temel bilimler arasında önemli olduğu düşüncesiyle eğitim fakülteleri müfredat programlarında yerini almıştır.

\section{Eğitim Tarihinin Önemi}

Eğitim tarihi toplumların zaman içerisinde değişim ve gelişimlerini eğitim boyutuyla inceleyen eğitimin diğer alanlarda etkisini inceleyen bir bilim dalıdır. Bu yönüyle eğitimin tarihi temellerinin öğrenilmesi; geçmişten günümüze eğitimin ve eğitim anlayışının hangi değişim ve dönüşümlerden geçtiğinin öğrenilmesi açısından önem taşıdığı gibi, geçmişte yapılan eğitim uygulamalarından dersler almayı, yapılan hataları tekrarlamamayı da sağlamaktadır. Ergün (2011)'e göre Eğitim tarihi; bir toplumun, bir ülkenin, bir kişi veya kurumun geçmişte kalmış ama gelecek kuşaklar için değerli olabilecek fikir, organizasyon ve uygulamalarıdır. Tarih, insanlığm ve insan topluluklarmm ortak bilincidir. Nasıl ki insan geçmişini hatırlamayınca şimdiki zamanı bilinçli olarak değerlendiremiyor ve geleceği sağlıkl planlayamıyorsa; tarih bilincinden yoksun bir insanlik ve insan topluluğu da aynı vaziyette bulunuyor demektir. Bu nedenle her toplum, kendi eğitim faaliyetlerinin, geçmişini ve tecrübelerini doğru olarak bilirse ve bunlardan yararlanırsa günümüzü daha sağlıklı değerlendirir ayrıca geleceğe yönelik sağlam planlar yapar. Güven (2019a)'e göre eğitim tarihi alanındaki çalışmalar geçmişten günümüze hafızalarda olan birikimleri, yaşanmışlıkları kitlelere yeniden hatırlatarak yapılan ve yapılması mümkün olacak yanlışlardan dönmeyi hedefleyen bir bilimdir.

Eğitim tarihinin önemine dikkat çeken düşünürlerimizden Necmeddin Sadak (1916) ise geçmiş asırlarda eğitimin nasıl yapıldığını, nasıl uyguladı- 
ğını ve ne şekilde gelişim gösterdiğini bilmenin en hakiki yolunun eğitim tarihini bilmekle olacağın şu cümlelerle dile getirmiştir: "Tarihi tetebbu bizi; bir mesleki terbiyeyi sebebi olmaktan veraset knlamaz. Fakat bize bir rehber bir şevk vazifesi görerek bir mesleğe sahip olmamıza yardım eder veya edindiğimiz mesleği tatbik ve tecrübeye müsaade eder". Eğitimle ilgili araştırmalar ancak tarihsel bir temele dayandırıldıkları takdirde doğru ve nesnel olarak değerlendirilir (Kamer ve Şimşek, 2016, s.665). Her milletin kendine özgü olan eğitim sistemi, o toplumun sosyal, kültürel, politik ve ekonomik özelliklerine uygun olarak kurulur ve gelişir (Duman, 2019). Bunun yanında ülkeler, günün ihtiyaçlarına uygun eğitim anlayış ve uygulamaları geliştirirken, eğitim sorunlarına kalıcı çözümler getirirken daha önce uygulanan eğitim anlayış ve uygulamalarını dikkate almak durumundadır (Güçlü, 2014). Bunun tarihsel temellerini belirleme görevi de eğitimin zaman içinde izlediği yolu inceleyen ve araştıran bir bilim dalı olan Eğitim Tarihine aittir.

\section{Türk Eğitim Tarihi Dersinin Gereği}

Türk eğitim tarihi, eğitim tarihimizle ilgili incelemeler bizim için mazi olmuş çeşitli eğitim kurumlarının kronolojik açıdan ve türlü olayların ayrıntılarıyla açıklanması yerine, kendi toplumumuzun geçmişte edindiği önemli eğitim deneyimlerinin incelenip ve değerlendirilmesine götürmesi açısından önemlidir. Bugünkü eğitim kurumlarımızın yeni şartlara ve ihtiyaçlara göre yeniden düzenlenmesi ve yaşanılan sorunları da ancak geçmişteki deneyimlerin doğru bir şekilde değerlendirilmesi Türk eğitim tarihini iyi bilmekten geçmektedir (Koçer, 1991, s.2). Türk eğitim tarihi eğitimin geçmişiyle ilgili rafine bilgi vermenin yanında öğretmen adaylarının genel kültür ve meslek bilgisi düzeylerinin gelişmesine hizmet eden bilim dalıdır (Taşdemirci, 2010,s.15).

Güven (2018b)'e göre; Türk eğitim tarihi, Türklerin Orta Asya'dan göç ettiği dönemlerden başlayıp, günümüze kadar eğitim ve öğretimin geçirdiği dönemleri inceleyen bir bilim dalıdır. Türer (2016)' Türk eğitim tarihin eğitimcilere sağlamış olduğu yararları şu şekilde sıralamıştır.

- Türk eğitim sisteminin toplumsal değişim ve dönüşüm serüvenimizin önemli ürünlerinden biri olan Türk eğitim sisteminin temel karakteristik özelliklerini belirleyen tarihsel, sosyal, ekonomik ve düşünsel dayanaklarını öğrenme ve öğretme. 
- Eğitimin toplumsal değişim süreci içinde nasıl bir rol üstlendiğini objektif bir biçimde değerlendirme.

- Türk eğitim sisteminin hangi düşünsel temelleri üstünde nasıl şekillendiğini belirleme.

- Eğitim sistemi içinde bugün yaşanan belli başlı sorun alanlarının tarihi geçmişini aydınlatma daha açık bir biçimde Türk eğitim tarihi ile ilgili objektif bir bakış açısına sahip olabilme.

- 21. yüzyılın bilgi toplumunun gereksinimlerine uygun bir biçimde Türk eğitim sisteminin çağdaşlaşmasını sağlama.

\section{Türk Eğitim Tarihinin Amacı}

Türk eğitim tarihinin amacı Akyüz (2019)'a göre; "en eski tarihlerden günümüze kadar Türk milletinin ürettiği, benimsediği, geliştirdiği eğitim ve öğretimle ilgili düşünceleri, kurumları, uygulamalar ortaya koymak, insan yetiştirme düzenini ve nasıl bir insan tipi yetiştirilmeye çalışıldığın araştırmak, Türk toplumlarmın mutluluğu ve mutsuzluğu ile eğitim ve öğretimlerinin ilişkisini araştırmak, bugünkü eğitim sorunlarımızı en iyi biçimde çözebilmek için geçmişten bir takım dersler çıkarılıp çıkarılamayacă̆ını tartışmaktır". Türk eğitim tarihinin ders niteliği kazanmasında, geçmişten günümüze kadar olan süreçte eğitimle ilgili görüş, öneri, düşünce, kurum ve kuruluşlarının tarihini aktaran, günümüzde yaşanılan eğitim sorunlarının tespitini yapmamıza ve sorunlara yönelik çözümler üretmemizin yanında eleştirel düşünme, sorgulama ve sorumluluk bilincinin gelişimine katkı sağlaması etkilidir. Ersöz ve Arıbaş (2014)'e göre Türk eğitim tarihi aracllığıyla Eğitim Fakültelerinin amaçlarından biri de, öğrencilere Türkiye'nin ve Türk dünyasının eğitim sorunlarını tarihi derinlik ve bütünlük içinde kavratmaya çalışmak ve onları, geçmiş tecrübelerden ders alarak çözüm arayışlarına yöneltmek olmalıdır. Güçlü (2016)'ya göre eğitim tarihinin en önemli amaçlarından birisi, geçmişten dersler çlkarmak ve gelecekte benzer hatalar yapmayarak sorunlara kalıcı çözümler üretmektir.

YÖK tarafından 1998'yılında eğitim tarihi, eğitim sosyolojisi ve eğitim felsefesi gibi derslerin öğretmenlere katkı vermeyeceği iddia edilerek eğitim fakültelerinde uygulanan eğitim programlarından çıkarılmıştır. Bu durum çoğu eğitimciler tarafından eleştirilmiştir. 1998-2006 yılları arası eğitim fakültelerinden mezun olan ve şuan görev yapan öğretmenlerin bu dersleri alma- 
dan mezun olmaları öğretmenlik yeterliliklerini tam anlamıla yerine getirmede güçlük yaşamalarına sebep olması kaçınılmazdır. 2006-2007 öğretim yılından itibaren genel kültür dersi olarak tekrardan iki saat ve iki kredili seçmeli ders olarak okutulmasına başlanılan Türk eğitim tarihi dersi 2018 yılında yapılan değişiklikle eğitim fakültelerinin bütün bölümlerinde zorunlu meslek bilgisi dersi olarak yerini almıştır. Eğitim fakülteleri yeni müfredat programında Türk eğitim tarihi ders içeriğini;

Türk eğitim tarihinin konusu, yöntemi ve kaynaklarl; ilk Türk devletlerinde eğitim; ilk Müslüman Türk devletlerinde eğitim; Türkiye Selçukluları ve Anadolu Beyliklerinde eğitim; Osmanh Devleti'nde eğitim: Illk yenileşme hareketlerine kadar eğitim sistemi; 13-18. Yüzyıllarda Osmanlı coğrafyası dışındaki Türk devletlerinde eğitim; Osmanlı Devleti'nde Tanzimat'a kadar eğitimde yenileşme hareketleri; Tanzimat'tan Cumhuriyete modern eğitim sisteminin kuruluşu; geleneksel eğitimin yeniden düzenlenmesi; 19-20. Yüzyllarda Avrasya'daki diğer Türk devlet ve topluluklarında eğitim; millî mücadele döneminde eğitim; Türkiye Cumhuriyeti'nde eğitim: Türkiye eğitim sisteminin temelleri, yapısı, kuruluşu ve gelişimi; başlangıcından bugüne öğretmen yetiştirme süreci; 21. Yüzyllda Türk dünyasında eğitim; ortak hedefler, dil ve alfabe birliği, ortak tarih yazma çalışmaları oluşturmuştur (YÖK, 2018).

Türk eğitim tarihi konusunda bilgi sahibi olmak, tarihsel olayları mukayese etme yoluyla günümüzü daha iyi anlayıp değerlendirme imkânı sağlamaktadır. Eğitim bilimlerinin ve uygulamalarını anlamak için sadece günümüzün bilinmesi yetersiz kalmaktadır. Bunun yanında tarihi derinliği de bilmemiz ve anlamamız gerekir. Tarihsel geçmişi ve birikimlerini bilmeden yeni görüss, öneri ve uygulamalar geliştirilemez. Tarih bilinmeden tarihi kökleri olan bir toplum oluşturulamaz; tarihini bilmeyen bireyler özgüvenleri yetersiz ve gelecek için amaçları olmayan toplum oluştururlar. Gerçek sadece şu anki durum değildir; onun tarihi kökleri ve gelecek boyutu da vardır; eğitim tarihi bilmek günün daha iyi sorgulanmasın ve geleceğin daha iyi değerlendirilmesini sağlar. Tarih, insanlara eleştirel görüş kazandırmanın en iyi yollarından biridir. Bir insanın hayatında doğru kararlar vermesinde onun tecrübelerinin büyük bir değeri olduğu gibi; bir ulusun doğru kararlar vermesinde de toplumsal tarihi tecrübelerin çok büyük bir değeri vardır (Öztürk ve Findıkçı, 2015, s.668).

Bu nedenle bir ülkede eğitim alanında çalışan teorisyen ve uygulayıcıların eğitim tarihi bilmesi, gerekli dersleri çıkarması beklenmektedir. Eğitim fakültelerinde okutulmakta olan Türk eğitim tarihi dersi de böyle bir amaç güt- 
mektedir (Güçlü ve Bozgeyikli, 2016, s.403). Lisans programlarında Türk eğitim tarihi dersi olmasını önemli görmektedirler. Katılımcıların dersi önemli bulma ile ilgili gerekçelerinde ise üst sıralarda "geçmiş dönemlerdeki eğitim hakkında bilgi sahibi olma, eğitim konusunda geçmiş hatalardan ders ç1karma ve eğitimde geldiğimiz noktanın kavranması" ifadeleri yer almıştır. Bu sonuç bizlere öğretmen adaylarının dersin varlığı hakkında olumlu düşünceye sahip oldukların göstermektedir (Alabaş, 2016, s.101).

Akyüz (2019) Türk eğitim tarihi dersinin gerekliliklerini beş madde halinde özetmektedir. Ona göre; eğitim sorunlarının kalıcı olarak çözümlenebilmesi, eğitim alanında yeni görüş ve önerilerin yapılabilmesi, öğretmenlerin mesleklerine sahip çıkabilmeleri, öğretmen ve öğretmen adaylarının mevcut politikaları eleştirip değerlendirebilmeleri, geçmiş eğitim uygulamalardan ders çıkarılabilmesi için Türk eğitim tarihi dersinin bilinmesi en önemli gereklilikleri oluşturmaktadır. Bunun yanında Akyüz, Türk eğitim tarihi bilmeyen öğretmenlerin mesleklerinin süregelen sorunlarından habersiz olacağını, güçlü bir meslek bilincinin kazanılamayacağını belirtmektedir (Güçlü ve Bozgeyikli, 2016, s.404).

Türk eğitim tarihi dersi ile öğretmen adayları Türk eğitim tarihinin dönemlerini ve bu dönemlerdeki eğitimin amac1, eğitim programı, öğretim yöntemleri, disiplin sağlama konularında bilgi sahibi olurlar. Öğretmen adaylarının Türk eğitim tarihi dersiyle (1) Türk eğitim tarihindeki olgu ve olayları bilmesi, (2) bu olgu ve olayları nedenleri, niçinleri, nasılları ve acabalarıyla sorgulama becerisi kazanması, (3) bu olgu ve olaylara farklı bir açıdan bakabilmesi, yorumlayabilmesi ve olumlu/ olumsuz yönde kritik yapabilmesinin sağlanması Türk eğitim tarihi dersinin amaçlarına en üst düzeyde ulaşılması açısından bir zorunluluktur. Erdem (2013)'e göre Türk eğitim tarihi dersinin Eğitim Fakültelerinin lisans programlarına alınmasıyla birlikte öğretmen adaylarının eğitim ve öğretmenlik mesleğiyle ilgili gelişmeleri tarihsel bir düzlemde inceleme, araştırma ve öğrenmesi yolunda önemli bir adım atılmıştır. Eğitim sistemimizin sorunlarını, neden ve uygulamalarıyla araştırma, inceleme ve eleştirme fırsatı da öğretmen adaylarına sunulmuştur (Arıkan, Ünver, Saraç ve Süzer'e 2007, 26).

$\mathrm{Bu}$ açıdan bakıldığında Türk eğitiminin tarihsel birikimini bu dersin olası kapsam ve içeriğiyle ilişkilendirerek düşünmek gerekmektedir. Geleneksel anlamda bu dersin amacı, öğretmen adayına Türk eğitim tarihinin içerdiği tarihsel gelişmeleri salt bilgi olarak aktarmak olmamalıdır. Türk eğitim tarihi 
dersi aracılı̆̆ıyla öğretmen adaylarının özellikle kendi alanındaki gelişmelere tarihsel bir bakış açısıyla yaklaşması, geçmiş ve güncel eğitsel olayları birbiriyle ilişkilendirmesi ve tartışması sağlanabilir. Böylelikle öğretmen adayı, kendi alanındaki gelişmeleri Türk eğitim tarihi çerçevesinde derinlemesine inceleyebilecek ve öğretmenlik mesleğine daha bilinçli yaklaşabilecektir. Türk eğitim tarihi dersi öğretmen adaylarına Türk eğitiminin geçmişteki durumunu, bugün gelmiş olduğu noktayı ve gelecekte de gelmesi gereken noktayı gösterme ve kavratma açısından oldukça etkili bir araçtır. Türk eğitim tarihi dersi sadece Türk eğitiminin günümüze kadarki tarihsel geçmişiyle ilgili bilgilerin verilmesi olarak değil; ayn zamanda Türk eğitiminde geçmişten günümüze kadar varolagelen eğitimsel olgular, olaylar üzerinde ve Türk eğitim tarihinin fikirsel yönüyle ilişkilendirerek güncel eğitim sorunlarımızın bize özgü çözümü konusunda "sorgulama" yapılmasi için bir fırsat olarak değerlendirilmelidir(Erdem,2013, s.443). Bu araştırma, öğretmen adaylarına Türk eğitim tarihi dersi aracıllğıyla Türk eğitim tarihindeki olgu ve olayların nedenleri ve niçinlerinin öğretilmesinin yanısıra, öğretmen adaylarının bu ders vasitasiyla "eleştirel düşünme, sorgulama ve sorumluluk" becerilerini ne boyutta geliştirdiklerinin ortaya konması amacıyla yapılmıştır.

\section{Yöntem}

\section{Araştırma Deseni}

Eğitim fakültesi öğrencilerinin Türk eğitim tarihi dersine yönelik düşünce ve bakış açılarının incelendiği bu araştırmada nitel bir araştırma deseni tercih edilmiştir. Katılımcların Türk eğitim tarihi dersine yönelik bakış açısı ve düşünce tarzlarını derinlemesine inceleyebilmenin nitel bir yaklaşımla daha mümkün olduğunun öngörülmesi nitel bir yaklaşım tercihinde etkili olmuştur. Ayrıca araştırma için gerçekleştirilen literatür taraması, bu konuda gerçekleştirilen araştırmaların azamisinin nicel bir desen tercih etmiş olduğunu göstermiştir. Bu araştırma kapsamında ise çalışılan olguların incelenmesinde nitel bir desenin daha derin anlam boyutları sağlayabileceği düşünülmüsstür.

\section{Verilerin Toplanması}

2018-2019 akademik yılı Bahar döneminde Aksaray Üniversitesi Eğitim Fakültesinde lisans eğitimi alan ikinci, üçüncü veya dördüncü sınıf öğrencileri 
programlarının bir gereksinimi olarak Türk eğitim tarihi dersi almıştır. Bu dersi alan öğrencilerden araştırmaya katılmayı gönüllü olarak kabul eden öğrenci sayısı 113 olup bu öğrencilerin bilgileri Tablo 1'de sunulmuştur.

Tablo 1. Araştırmaya Katılan Öğrencilerin Bölüm, Sınıf Düzeyi ve Sayıları

\begin{tabular}{|c|c|c|}
\hline Sınıf Düzeyi & Bölüm & Say1 \\
\hline \multirow{2}{*}{ İkinci Sınıf } & İngilizce Öğretmenliği & 15 \\
\hline & Rehberlik ve Psikolojik Danışmanlık & 32 \\
\hline Üçüncü Sınıf & Sosyal Bilgiler Ö̈̆retmenliği & 20 \\
\hline \multirow{2}{*}{ Dördüncü Sınıf } & Türkçe Öğretmenliği & 23 \\
\hline & Sınıf Öğretmenliği & 33 \\
\hline Toplam & & 113 \\
\hline
\end{tabular}

Tablo 1'de görüldüğü üzere İngilizce Öğretmenliği ve Rehberlik ve Psikolojik Danışmanlık öğrencileri dersi ikinci sınıfta almış olup toplam sayıları 47'dir. Sosyal Bilgiler Öğretmenliği bölümü öğrencileri dersi programlarının üçüncü yılında almıştır ve sayıları 20'dir. Son olarak Türkçe Öğretmenliği ve Sınıf Öğretmenliği öğrencileri dersi dördüncü sınıfta almıştır ve toplam say1ları 56'dır. Bu doğrultuda araştırmaya toplam katılımcı sayısı 113 öğrencidir.

Verilerin toplanması aşamasında dönem sonu ders bittikten sonra öğrencilere "Bu ders eleştirel düşünme, sorgulama ve sorumluluk anlamında size ne kattı?" Açık uçlu sorusu bulunan bir form vererek toplanmıştır. Veri toplama formunun cevaplanmasında gönüllülük ilkesi esas alınmıştır. Bu bağlamda gönüllü olarak formu alıp dolduran öğrencilerden gelen yanıtlarla veri seti oluşturulmuştur.

\section{Verilerin Analizi}

Veriler içerik analizi tekniği kullanılarak analiz edilmiştir. Nitel veri analizi, veri toplama süreci bittikten sonra değil, verilerin toplanmasıyla başlar. Ayrıca veri analizi, veri toplama ile verilerden anlam çıkarma süreci arasında gidiş ve gelişleri içeren tekrarlı bir süreçtir (Teddlie ve Tashakkori, 2015). Bu doğrultuda verilerin analizinde içerik analizi kapsamında kodlar oluşturulmuş, oluşturulan kodlar sürekli bir şekilde verilerle karşılaştırılarak bulgulara ulaşılmıştır.

İçerik analizi tekniği kapsamında kodların oluşturulması için açık kodlama yolu tercih edilmiştir (Burnard, Gill, Stewart, Treasure ve Chadwick, 
2008). Veri seti öncelikle okunarak veriler üzerinde notlar alınmış, ardından alınan notlar doğrultusunda ilk kod listesi meydana getirilmiştir. Oluşturulan ilk kod listesi veriler doğrultusunda yeniden incelenerek tekrarlar çıkarılmış ve kod listesine son hali verilmiştir.

\section{Güvenilirlilik}

Oluşturulan kodların güvenilirliğini sağlamak amaciyla Miles ve Huberman (1994) tarafından tanımlanan formül kullanılmıştır.

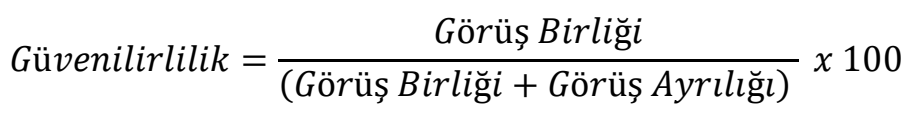

Veri analizi kısmında açıklanan açık kodlama ve kodlara son halini verme yolu araştırmacı tarafından gerçekleştirildiği gibi eğitim programları ve öğretim alanında doktora yapmış ve nitel araştırma deneyimi bulunan başka bir araştırmac tarafından da gerçekleştirilmiştir. Oluşturulan kod listelerinde iki uzmanın durumlar için kullandıkları kodların aynı yahut oldukça benzer olduğu kodlar görüş birliği, farklı kodlar ise görüş ayrıllğı olarak belirlenmiştir. Belirtilen güvenilirlilik formülü doğrultusunda kodlayıcılar arasındaki ortalama güvenilirlilik \%90 olarak bulunmuştur. Kodların güvenilirliliği bu şekilde sağlandıktan sonra kodların benzerliklerine göre temalar oluşturulmuştur. Kodları da içeren temalar iki eğitim bilimleri uzmanına sunularak görüş̧ istenmiştir. Uzmanlardan gelen dönütler doğrultusunda gerekli düzeltmeler yapılarak temalara son şekli verilmiştir. Bu temalar, bulgu başlıkları olarak sunulmuştur.

\section{Etik Hususlar}

Nitel araştırmalarda araştırmacının ehemmiyet vermesi gereken en önemli hususlardan biri de araştırmaya katılan kişileri araştırmaya gönüllü olarak dahil etme ve araştırma raporunda katılımcıların gizliliklerini muhafaza etmedir. Bu araştırmada veri toplanan öğrenciler araştırmanın amaç ve kapsamından haberdar edilmiş ve gönüllü olanlar araştırmaya katılmıştır. Verilerin toplanması amaciyla kullanılan formda öğrencilerden kişisel bilgi istenmemiştir. Ayrıca verilerin sunumunda katılımcıların yanıtlarından alıntılar 
yapılırken katılımcların kimliklerini açı etmeyecek kod ifadeleri kullanılmıştır. Kodların seçiminde öğrencilerin bölümleri kısaltılıp bu kısaltmalara numaralar eklenmiş ve bu sayede katılımc kodları belirlenmiştir. İngilizce Öğretmenliği bölümü öğrencileri İÖ, Rehberlik ve Danışmanlık bölümü öğrencileri RPD, Sosyal Bilgiler Öğretmenliği bölümü öğrencileri SBÖ, Türkçe Öğretmenliği bölümü öğrencileri TÖ ve Sınıf Öğretmenliği öğrencileri SÖ olarak kodlanmıştır. Şu hâlde, SBÖ1 kodu, Sosyal Bilgiler Öğretmenliği bölümünden analize alınan ilk öğrenciyi temsil etmektedir.

\section{Sinirliliklar}

Bu araştırmada kullanılan veriler Aksaray Üniversitesi, Eğitim Fakültesi İngilizce Öğretmenliği, Rehberlik ve Danışmanlık, Sosyal Bilgiler Öğretmenliği, Türkçe Öğretmenliği ve Sınıf Öğretmenliği bölümü öğrencilerilerinin vermis olduğu cevaplarla sinırlıdır.

\section{Bulgular}

Aksaray Üniversitesi, Eğitim Fakültesi lisans öğrencilerinin programları kapsamında almış oldukları Türk eğitim tarihi dersine yönelik görüş, düşünce ve bakış açılarının incelendiği bu araştırmada veri analizi sonucunda ulaşılan tema ve alt temalar Tablo 2'de verilmektedir.

Tablo 2. Katılımcıların Türk eğitim tarihi Dersine Yönelik Görüş, Düşünce ve Bakış Açıları

\begin{tabular}{lll}
\hline Tema & \multicolumn{2}{l}{ Alt Tema } \\
\hline Beceri ve Bilinç Geliştirme & $\bullet$ & Düşünme Becerilerini Geliştirme \\
& $\bullet$ & Eleştirel Düşünme Becerisi \\
& $\bullet$ & Çok Boyutlu Düşünme Becerisi \\
& $\bullet$ & Sorgulams Düşünme Becerisi \\
& & \\
\hline Eğitimin Değer ve Gerekliliğininin Farkandırma \\
Varma & & \\
\hline Geleceği İnşa Edebilmek İçin Geçmişten Ders & \\
Çıkarma & \\
\hline
\end{tabular}

Tablo 2'den görülebildiği gibi katılımcıların Türk eğitim tarihi dersine yönelik görüş, düşünce ve bakış açıları Beceri ve Bilinç Geliştirme, Eğitimin 
Değer ve Gerekliliğinin Farkına Varma ve Günümüzü Kurabilmek İ̧̧in Geçmişten Ders Çıkarma olmak üzere üç ana tema etrafında toplanmaktadır. Bu temalar bulgular kısmının devamında sırasıyla sunulmuştur.

\section{Beceri ve bilinç geliştirme}

Veri analizi neticesinde birinci ana tema Beceri ve Bilinç Geliştirmenin, Düşünme Becerilerini Geliştirme (Eleştirel, Çok Boyutlu ve Bağımsız), Sorgulama Becerisi Kazandırma ve Bağımsız Düşünme Becerisi alt temaları doğrultusunda incelenebileceği görülmüştür. Bu tema altında katılımcıların Türk eğitim tarihi dersine yönelik olarak en sık dile getirdikleri görüşleri, bu dersin düşünme becerilerini geliştirmede kendilerine fayda sağladığı görülmüştür. Ayrıca bu düşünme becerilerinin tek bir boyutta toplanmadığı, aksine, eleştirel düşünme becerilerini geliştirme, çok boyutlu düşünme becerilerini geliştirme ve bağımsız düşünme becerilerini geliştirme olmak üzere üç boyutta ele alınabileceği görülmüştür.

\section{Düşünme becerilerini geliştirme}

Eleştirel düşünme becerilerini geliştirme: Katılımcılara göre Türk eğitim tarihi dersini almış olmaları eğitim alanına bakış açlarında eleştirel bir düşünce yapısı edinmelerine katkı sağlamıştır. Nitekim bu durum bazı katılımcılarda öncelikle eleştirel düşünme konusunda yetersizliğinin farkına varma biçiminde belirmiştir. PDR4: [Bu ders sayesinde eleştirel düşünme, sorgulama becerisi konusunda yeterli olmadığımı hissettim]. Bazı katılımcılar da ise bu durum, eleştirel düşünme becerisinin olduğundan daha da geliştirilmesine katkı sağlamıştır. PDR22: [Bu ders, doğrular ve yanlışlar hakkında eleştirel düşünme tarzımın gelişmesine katkı să̆ladı. Bu ders, olaylara bir açıdan değil farkh açılardan bakmamı sağladi]. SÖ9: [Bu dersle ylllardır sorgulamadan dümdüz öğrendiğimiz bilgileri eleştirmemi, sorgulamamı gerektiğini fark ettim]. SÖ23: [Ĕ̈itim sistemi hakkında eleştirel düşünmeye başladım. Eleştirel düşünme ve farklı açılardan düşünme becerilerimiz gelişti]. TÖ23: [Türk Ĕ̆itim Tarihi dersi bir öğretmen adayı olarak düşünen, inceleyen, araşttran bireyler yetiştirmem gerektiğini, ezberciliğin kalıcı olmadığını, mantığın ve fikirlerin değerli olduğunu gösterdi]. PDR19: [Türk eğitim tarihi dersi, geçmişi eleştiri süzgecinden geçirerek sağlam eğitim politikalarn geliştirmek için bana umut kazandırdı]. TÖ1: [Türk eğitim tarihi dersi olaylara daha objektif bakmamı ve 
eğitimimizdeki aksaklıkları görmemi ve eleştirebilmemi sağladı. Bu ders sayesinde eğitimde geri kalmamızı sorgulattı ve düşündürdü. Bu sorunlarn üzerinden gelinmesi açısından çözüm üretme fikirleri verdi ]. IOÖ10: [Türk eğitim tarihi dersi bana olaylara tarafsı bakmayı ögretti. Bir konu hakkında sadece olumlu yanları değil, olumsuz yanları da eleştirmeyi öğretti].

Çok Boyutlu Düşünme Becerilerini Geliştirme: Eleştirel düşünme becerilerini geliştirmekle birlikte katılımclara göre Türk eğitim tarihi dersi aynı zamanda eğitsel olay ve olguları çok boyutlu düşünebilme becerilerinin gelişimini de olumlu etkilemiştir. IOÖ12: [Bu ders benim ufkumu açtı, olaylara bir pencereden değil de birçok açıdan bakmam gerektiğini öğretti]. PDR24: [Bu ders sayesinde olaylara karşı tek yönlü olarak değil eleştirel bakıyorum, böylece yorum yapabilme kabiliyetim gelişiyor]. SÖ15: [Türk eğitim tarihi olaylara bakış açımı değiştirdi. Olaylara farklı açılardan bakmamı sağladı]. SÖ16: [Derste sorulan bir soruyu düşünürken değişik yerler ile bağlantı kurmayı fark etmemi să̆ladı. Olaya bir açıdan değil, farklı yönlerden bakmayı öğrendim]. SÖ18: [Ĕ̆itimle ilgili yapılan çalışmaların temelinin nereden geldiğini ve uygulamaların artıların ve eksilerini daha iyi görmemi sağladı. Kulaktan dolma bilgilerin yanlış olduğunun farkına vardım. Yapılan bir çalışmanın zamanında ve yaşanan olaylan göz önüne alarak değerlendirilmesi gerektiğini gördüm. Eğitimle ilgili uygulamalarm daha iyi nasıl olabilir düşüncesi ile sorgulama yeteneğ $i$ ve disiplinler arasındaki iliskiyi daha iyi anladım]. SBÖ13: [Bu ders bana olaylara eleştirel gözle bakmayı, bir konuya sade bir gözden yaklaşmak yerine çeşitli fikirlerden faydalanarak yaklaşmayı ve objektif olmayı öğretti].

Bağımsız Düşünme Becerilerini Geliştirme: Türk eğitim tarihi dersinin eleştirel düşünme becerilerini ve çok boyutlu düşünme becerilerini geliştirme ile birlikte bir diğer katkısı da öğretmen adaylarına bağımsız düşünme becerisi kazandırmaktır. TÖ6: [Türk eğitim tarihi dersi bana birçok alanda sorgulama ve sorumluluk duygusu kattı. Bir görüşe körü körüne inanmaktansa kendi fikrimi savunmam gerektiğini bana aşıladi]. SÖ7: [Her söylenene inanmamal, kendi düşüncelerimizi geliştirmeliyiz. Birisi benim yerime düşünmüş deyip de hazıra konmamal-yız. Bizim de fikirlerimiz olmal. Bu ders sayesinde neden sonuç ilişkisini kurmayı daha çok öğrendim]. İÖ9: [Türk eğitim tarihi bana kendimizi geliştirmemizin ne kadar önemli olduğunu gösterdi. Zihnimizi ve aklımızı kimsenin emri altına sokma- 
mamı gerektiğini öğretti. Düşünebildiğimiz sürece kendi gördüklerimizi ve bildiklerimizi analiz etmeyi bilmeliyiz. Başkalarmdan duyduklarımızla ve başkasının söyledikleriyle kendimizi yönlendirmemeliyiz].

\section{Sorgulama becerisi kazandırma}

Katılımcların düşünce yapısında dikkat çeken bir diğer husus, katılımcıların Türk eğitim tarihi dersinin sorgulama becerilerine olumlu etkisinin olduğunu düşünmeleridir. Sorgulama becerisi kazandırma özelliği bir önceki alt temada tartışılan düşünme becerilerini geliştirme özelliği ile ilintili olarak düşünülmelidir, zira düşünme becerilerinin gelişmesi sorgulama becerisini etkilediği gibi sorgulama becerisinin gelişmesi de düşünme becerilerini tetiklemektedir. PDR31: [Bu ders sayesinde sorgulama becerim gelişti, eleştirel gözle bakmam gerektiğini fark ettim]. TÖ14: [Bu ders bana geçmişten günümüze kadar olan süreçte olay ve olgular üzerinden eğitim sistemimizi değerlendirmeyi, olumlu ve olumsuz yönleri ile gözlemleyip sorgulayabilmeyi ve ileride öğretmen olursam nasıl bir sistem üzerinden hareket etmem gerektiğini ögrretti]. SBÖ10: [Bir öğretmen adayı olarak bu ders eăitimin geçmişten günümüze nasıl geldiğini görerek o zamanki durumla şimdiyi karşılaştırarak ve sorgulayarak bakmamı sağladı]. SBÖ15:[Olayları ve olguları yeterince eleştiremediğimi, üzerine düşünemediğimi, sorgulamadığımı ve öğretmenlik açısından sorumluluktan kaçtı̆̆ımı, kendimi geliştirmek adına uğraşmadığımı fark ettirdi].

\section{Sorumluluk Bilinci Kazandırma}

Katılımcların bakış açısından Türk eğitim tarihi dersinin bir diğer katkısı, bu dersin öğretmen adaylarına sorumluluk bilinci kazandırmasıdır. Burada bahsedilen sorumluluk bilinci, öğretmen adaylarının düşünme becerilerinin gelişmesiyle birlikte ileride kariyer yapacakları alanın getirdiği yüklere yönelik bir duydukları sorumluluk ile ilgilidir. Nitekim bu hususta PDR16 kodlu öğretmen adayı şu ifadeleri kullanmıştır: [Türk eğitim tarihi dersi bana öncelikle sorgulama ve karşılama becerisi kazandırdı. Bu sayede öğretmen adayı olarak sorumluluk bilincimin artmasını sağladı]. PDR26: [Bu ders sayesinde devlet kurmamın, devlet yıkmanın; ticari, sosyal hayatın ve birçok şeyin eğitimden geçtiğini anladım. Bu bana daha çok sorumluluk kazandırıp, daha geniş açıdan bakmayı sağladı]. Sorgulamanın gerekliliği ve sorgulama sonucunda oluşan sorumluluk bilinci 
hususunda SÖ10: [Bir öğretmen adayı olarak Türk eğitim tarihi dersinde ülkelerin eğitim sistemi ile kendi ülkemizdeki eğitim sistemini karşılaştırdım. Bizim ülkemizdeki eğitimde ne eksik diye sorguladım, neler yapılabilir diye düşündüm. Biz Öğretmenler olarak nasıl eğitim vermeliyiz ve çocukları nasıl yetiştirmeliyiz diye sorguladım] ifadesini kullanmıştır. SÖ21: [Türk eğitim tarihi dersi bana öncelikle sorgulama ve karşılaştırma becerisi kazandırdı. Türkiye'deki ve dünyadaki eğitim sistemlerini karşılaştırma imkânı sundu. Bu karşılaştırmalar sonucunda üstümdeki sorumluluk bilincinin arttı̆̆ın düşünüyorum]. SÖ28: [Geçmişte yaptığımız hataları, bu hatalarm sebeplerini ve tekrar bu hatalara düşmemek için ne yapabiliriz, bunun bilincine ve sorumluluğuna erişmiş oldum]. SBÖ8: [Türk eğitim tarihi dersi neden ve nasıl sorularna cevap bulmamı sağlad. Eleştirel düşünerek dünü ve bugünü kıyaslayabildim. Şimdiki zamanın değerini anlayıp sorumluluk sahibi olmam gerektiğini anladım]. TÖ16: [Bu ders sayesinde her şeyi araştırıp düşünmenin biz öğretmen adaylarnın görevi olduğunu anladım. Çünkü bizler bir nesil yetiştireceğiz. Onlara gerçekleri, görünmeyen şeyleri göstermek bizim görevimiz].

\section{Eğitimin Değer ve Gerekliliğinin Farkına Varma}

Veri analizi sonucunda ulaşılan ikinci tema, öğretmen adaylarının Türk eğitim tarihi dersi sayesinde eğitimin değer ve gerekliliğini daha iyi idrak etmiş olduklarını belirtmiş olmalarıdır. Oldukça yaygınlaşmış ve hatta klişeleşmiş bir söylem olmakla birlikte eğitim bir toplumun ekonomik, sosyal ve kültürel alanlarda ilerlemesi için sine qua non'dur (olmazsa olmazdır). Bu durumu en iyi içselleştirmesi gereken toplum grubu ise hiç kuşkusuz, öğretmenlerdir, çünkü bireysel ilgi ve ihtiyaçlar dikkate alınarak toplumun ihtiyaç duyduğu karakterde yeni nesillerin yetiştirilmesi görevi öğretmenlerin omuzlarında olacaktır. Katılımcılara göre Türk eğitim tarihi dersi eğitimin değer ve gerekliliğini içselleştirerek bu doğrultuda topluma hizmet sunma algısı kazanmalarında etkili olmuştur.

IÖ2: [Ĕ̆itimin bir millet açısından ne düzeyde kritik sonuçlar doğurabileceğini öğrendim]. İÖ4: [Türk eğitim tarihi bana eğitimin bir toplumun geleceğgi, refahı ve var oluşu açısından ne ölçüde önemli olduğu bilgisini kazandırdı]. SÖ22: [Bir öğretmen adayı olarak bu ders bana eğitim sistemi nasıl olmalı, nasıl olsa daha iyi olur sorularının cevabında katkı sağladı. Eğitimin ne kadar önemli olduğunu anladım]. TÖ18: [Ĕ̆itimin ülkeler arasında çok önemli olduğunu ve her şeyi değisstirebileceğini 
öğrendim]. İÖ10: [Tarihin eğitimle ilgili olan kısmmn daha iyi değerlendirir hale getirdi ve bir toplumu bozmak istersek önce eğitimden başlamalıyı sözünü daha net bir şekilde anlamamı sağladı]. İÖ5: [Türk eğitim tarihi dersi bir toplumun en büyük silahının eğitim olduğunu gösterdi. Bunun için her birey kendini geliştirmeli ve aklını kullanmalıdır].

\section{Geleceği İnşa Edebilmek İçin Geçmişten Ders Çıkarma}

Katılımcıların bakış açısından Türk eğitim tarihi dersinin bir diğer katkısı da gerek eğitim sistemini gerekse de eğitim sayesinde toplumsal ve iktisadi açıdan günümüz dünyasını sağlıklı bir şekilde kurmada tarihsel gelişmelerin bilincinde olma ve tarihi eleştirel olarak değerlendirip ondan dersler çıkarmadır. Bu bulgu, bir bakıma 'geçmişini bilmeyen, geleceğini kuramaz' deyişinin bu çalışma kapsamındaki tezahürüdür. Öğretmen adayları, bu konuyla ilgili olarak ya geçmişte yaşanan eğitsel gelişmelerden gerekli dersler çıartılmadığını dile getirmiş ya da geçmişten gerekli dersler çıkartılmadıkça atılacak adımların istenen sonuçları vermeyeceğini ifade etmiştir.

IÖ2: [Geçmişte eğitimde aldığımız darbelerden hala ders çıkarmamış olduğumuz fark ettim]. İÖ3: [Türk eğitim tarihi dersi bana geçmişten ders almadan geleceğgi şekillendiremeyeceğimizi gösterdi]. TÖ20: [Türk eğitim tarihi dersi, geçmişte yapılan hataları öğrenip eğitimi yeniden reform edebilmek için yeni bir firsat]. SBÖ12: [Dersi almadan önce eğitim tarihinin çok gereksiz olduğunu, bilmesem de bir şey kaybetmeyeceğini düşünürken dersi aldıktan sonra geçmişini bilmeyenin geleceğinde de ayn hatalar tekrarlayabileceğini öğrendim]. TÖ17: [Bu ders geçmişteki eğitim programları ve eğitim süreçlerine bakmamızı sağlayarak günümüz şartlarını yeniden üretme ve yeniden düşünme becerisi kazandırdı]. TÖ2: [Türk eğitim tarihi dersi geçmişten günümüze eğitimde yaşanan birçok olaya daha sorgulayıcı ve dikkatli bakmamı sağladı... Bir sorunu çözerken geçmişten bugüne değişen ve gelişen tüm özellikleri dikkate almaya başladım]. TÖ1: [Türk eğitim tarihi dersi olaylara daha objektif bakmamı ve eğitimimizdeki aksaklıklarn görmemi ve eleştirebilmemi sağladı. Bu ders sayesinde geçmişte geri kalmamızı eğitim açısından sorgulattı ve düşündürdü. Bu sorunların üzerinden gelinmesi açısında bize çözüm üretme fikirleri verdi]. SBÖ10: [Bir öğretmen adayı olarak bu derste eğitimin geçmişten günümüze nasıl geldiğini görerek o zamanki durumla şimdiyi karşılaştırmamı ve sorgulamamı sağladı. Nasıl tarihini bilmeyen insan eksikse eğitim Tarihini bilmeyen öğretmen de bir adım geridedir]. SBÖ7: [Eğitim sistemimizdeki yanlışlarn ve eksiklikleri görmemizi sağlayarak dünle 
bugünü karşılaştırma imkânı verdi]. SBÖ4: [Türk eğitim tarihi dersi bana geçmişteki eğitim sistemini öğrenip eleştirip gelecekte nasıl bir öğretmen olmam gerektiğini öğretti. Sorgulamadan bir işe körü körüne bağlanmamam gerektiğini, ileride sorgulayan bireyler yetiştirmem gerektiğini öğretti]. SÖ30: [Türk vatandaşı olarak, özellikle de öğretmen olarak, geçmişe bakarak ders çıkarmaya ve gelecekteki nesillere bunu aktarmanın gerektiği bilincine vardım]. PDR31: [Bu ders sayesinde geçmişte yaptığ ${ }^{-}$ miz hataları gördüm ve bu hatalarm sebeplerini tekrar etmemek ve bu hatalara düşmemek için neler yapabilirizin bilincine ve sorumluluğuna erişmiş oldum]. SÖ6: [Öncelikle geçmişi anlamayı ve ondan ders çıkarmayı öğretti. Bu ders geçmişte yapılanları günümüzde yapılanlarla bağ kurarak daha iyi anlamamı sağladı]. İÖ15: [Bu dersten çıkarılması gereken tecrübeler, sadece geçmişle övünme yerine ondan ders alıp dersler çıkarmak, bilimin her devirde yol gösterdiğini daha iyi anlamak, sorgulamanın ve tartısmanın önemini kavramaktır].

\section{Tartışma ve Sonuç}

Aksaray Üniversitesi, Eğitim Fakültesi lisans öğrencilerinin programları kapsamında almış oldukları Türk eğitim tarihi dersine yönelik görüş, düşünce ve bakış açıları incelendiğinde; Beceri ve Bilinç Geliştirme, Eğitimin Değer ve Gerekliliğinin Farkına Varma ve Günümüzü Kurabilmek İçin Geçmişten Ders Çıkarma gibi üç ana tema etrafında toplandığı ve bu temalara bağlı olarak;

- Düşünme Becerilerini Geliştirme

- Eleştirel Düşünme Becerisi

- Çok Boyutlu Düşünme Becerisi

- Bağımsız Düşünme Becerisi

- Sorgulama Becerisi Kazandırma

- Sorumluluk Bilinci Kazandırma gibi alt temaların oluştuğu görülmüştür.

Beceri ve bilinç geliştirme: Beceri ve Bilinç Geliştirmenin, Düşünme Becerilerini Geliştirme (Eleştirel, Çok Boyutlu ve Bağımsız), Sorgulama Becerisi Kazandırma ve Bağımsız Düşünme Becerisi alt temaları doğrultusunda katılımcıların Türk eğitim tarihi dersine yönelik olarak en sık dile getirdikleri görüşleri, bu dersin düşünme becerilerini geliştirmede kendilerine fayda sağladığı görülmüştür. Düşünme becerilerini geliştirme boyutuyla bakıldı̆̆ında 
Türk eğitim tarihi dersinin eleştirel düşünme becerilerini geliştirme konusunda etkili olduğu görülmüsstür. Katılımclara göre Türk eğitim tarihi dersini almış olmaları, eğitim alanına bakış açılarında eleştirel bir düşünce yapısı edinmelerine katkı sağlamıştır. Nitekim bu durum bazı katılımcılarda öncelikle eleştirel düşünme konusunda yetersizliğinin farkına varma biçiminde belirmiştir. Bu beceriler doğrultusunda katılımcıların;

Türk eğitim tarihi dersi katılımclarda eleştirel düşünme, sorgulama becerisi konusunda yeterli beceriye sahip olunmadığını ortaya koyarken, doğrular ve yanlışlar hakkında eleştirel düşünme tarzının gelişimine, olaylara bir açıdan değil farklı açlardan bakılmasını, yıllardır sorgulamadan dümdüz öğrenilen bilgilerin eleştiri süzgecinden geçirilmesini ve sorgulanmasının önemli olduğunu kazandırmıştır. Türk eğitim tarihi dersi, öğretmen adaylarına düşünen, inceleyen, araştıran bireyler yetiştirmenin gerekliliğini, ezberciliğin kalıcı olmadığını, mantığın ve fikirlerin değerli olduğunu göstermiştir. Türk eğitim tarihi dersi, geçmişi eleştiri süzgecinden geçirerek sağlam eğitim politikaları geliştirmek için umut kazandırması, olaylara daha objektif bakmasını ve eğitimimizdeki aksaklıkların görülmesini sağlaması açısından öğrencilere eleştirel düşünme becerisi kazandırıldığı görülmüştür. Ayrıca bu ders katılımclara eğitimde geri kalmamızı sorgulatması ve bu konuda düşündürmesi var olan sorunların üzerinden gelinmesi açısından çözüm üretme fikirlerini verdiği görülmüştür. Çok Boyutlu Düşünme Becerilerini Geliştirme açısından bakıldığında eleştirel düşünme becerilerini geliştirmekle birlikte katılımcılara göre Türk eğitim tarihi dersinin ayn zamanda eğitsel olay ve olguları çok boyutlu düşünebilme becerilerinin gelişimini de olumlu etkilediği görülmüştür. Türk eğitim tarihi dersi ayrıca katılımcılarda, olaylara bir pencereden değil de birçok açıdan bakma, derste sorulan bir soruyu düşünürken değişik yerler ile bağlantı kurmayı fark ettirme, eğitimle ilgili uygulamaların daha iyi nasıl olabilir düşüncesi ile sorgulama yeteneği ve disiplinler arasındaki ilişkiyi daha iyi anlama becerilerini de kazandırmıştır. Bağımsız Düşünme Becerilerini Geliştirme boyutuyla bakıldığında Türk eğitim tarihi dersinin eleştirel düşünme becerilerini ve çok boyutlu düşünme becerilerini geliştirme ile birlikte bir diğer katkısı da öğretmen adaylarına bağımsız düşünme becerisi kazandırmıştır. Katılımclların düşünce yapısında dikkat çeken bir diğer husus ta, katılımcıların Türk eğitim tarihi dersinin sorgulama becerilerine olumlu etkisinin olduğunu düşünmeleri olmuştur. Sorgulama becerisi kazandırma özelliği bir önceki alt temada tartışılan düşünme 
becerilerini geliştirme özelliği ile ilintili olarak düşünülmelidir. Zira düşünme becerilerinin gelişmesi sorgulama becerisini etkilediği gibi sorgulama becerisinin gelişmesi de düşünme becerilerini tetiklemektedir. Katılımcıların bakış açısından Türk eğitim tarihi dersinin bir diğer katkısı ise, bu dersin öğretmen adaylarına sorumluluk bilinci kazandırmasıdır. Burada bahsedilen sorumluluk bilinci, öğretmen adaylarının düşünme becerilerinin gelişmesiyle birlikte ileride kariyer yapacakları alanın getirdiği yüklere yönelik bir duydukları sorumluluk ile ilgili olduğu görülmüştür. Nitekim bu hususta öğretmen adaylarının şu ifadelerini tekrar buraya alıntılanması konunun önemi açısından değerli görülmüştür:

1- Türk eğitim tarihi dersi bana öncelikle sorgulama ve karşılaştırma becerisi kazandırdı. Bu sayede öğretmen adayı olarak sorumluluk bilincimin artmasını sağladı.

2- Bu ders sayesinde devlet kurmanın, devlet yıkmanin; ticari, sosyal hayatın ve birçok şeyin eğitimden geçtiğini anladım. Bu bana daha çok sorumluluk kazandırıp, daha geniş açıdan bakmayı sağladı.

3- Bir öğretmen adayı olarak Türk eğitim tarihi dersinde ülkelerin eğitim sistemi ile kendi ülkemizdeki eğitim sistemini karşılaştırdım. Bizim ülkemizdeki eğitimde ne eksik diye sorguladım, neler yapılabilir diye düşündüm. Biz Öğretmenler olarak nasıl eğitim vermeliyiz ve çocukları nasıl yetiştirmeliyiz diye kendimi sorguladım.

4- Türk eğitim tarihi dersi neden ve nasıl sorularına cevap bulmamı sağladı. Eleştirel düşünerek dünü ve bugünü kıyaslayabildim. Şimdiki zamanın değerini anlayıp sorumluluk sahibi olmam gerektiğini anladim.

5- Bu ders sayesinde her şeyi araştırıp düşünmenin biz öğretmen adaylarının görevi olduğunu anladım. Çünkü bizler bir nesil yetiştireceğiz. Onlara gerçekleri, görünmeyen şeyleri göstermek bizim görevimiz.

Veri analizi sonucunda ulaşılan ikinci tema ise öğretmen adaylarının Türk eğitim tarihi dersi sayesinde eğitimin değer ve gerekliliğini daha iyi idrak etmiş olduklarını belirtmiş olmalarıdır. Oldukça yaygınlaşmış ve hatta klişeleşmiş bir söylem olmakla birlikte eğitim bir toplumun ekonomik, sosyal ve kültürel alanlarda ilerlemesi için sine qua non'dur (olmazsa olmazdır). Bu durumu en iyi içselleştirmesi gereken toplum grubu ise hiç kuşkusuz, öğretmenlerdir, çünkü bireysel ilgi ve ihtiyaçlar dikkate alınarak toplumun ihtiyaç duyduğu karakterde yeni nesillerin yetiştirilmesi görevi öğretmenlerin 
omuzlarında olacaktır. Katılımclara göre Türk eğitim tarihi dersi eğitimin değer ve gerekliliğini içselleştirerek bu doğrultuda topluma hizmet sunma algısı kazanmalarında etkili olmuştur. Bu doğrultuda Türk eğitim tarihi dersinin, öğretmen adaylarına eğitimin bir millet açısından ne düzeyde kritik sonuçlar doğurabileceğini, eğitimin bir toplumun geleceği, refahı ve var oluşu açısından ne ölçüde önemli olduğunu, bir öğretmen adayı olarak bu dersin eğitim sistemin nasıl olması gerektiği ayrıca bir toplumun en büyük silahının eğitim olduğu düşüncelerini kazandırdığı sonucuna ulaşılmıştır.

Öğretmen adaylarının bakış açısından Türk eğitim tarihi dersinin bir diğer katkısı da gerek eğitim sistemini gerekse de eğitim sayesinde toplumsal ve iktisadi açıdan günümüz dünyasını sağlıklı bir şekilde kurmada tarihsel gelişmelerin bilincinde olma ve tarihi eleştirel olarak değerlendirip ondan dersler çıkarmadır. Bu bulgu, bir bakıma "geçmişini bilmeyen, geleceğini kuramaz" deyişinin bu çalışma kapsamındaki tezahürüdür. Öğretmen adayları, bu konuyla ilgili olarak ya geçmişte yaşanan eğitsel gelişmelerden gerekli dersler çıkartılmadığını dile getirmiş ya da geçmişten gerekli dersler çıkartılmadıkça atılacak adımların istenen sonuçları vermeyeceğini ifade etmişlerdir. Bu doğrultuda öğretmen adaylarınca; Türk eğitim tarihi dersinin, özellikle Türk vatandaşı ve bir öğretmen adayı olarak, geçmişe bakarak ders ç1karmanın ve gelecekteki nesillere bunu aktarmanın gerekliliği bilincine varılmasını sağlamakla beraber, tecrübelerin, sadece geçmişle övünme yerine onlardan ders alıp dersler çıkarma, bilimin her devirde yol gösterici olduğunu daha iyi anlama, sorgulama ve tartışmanın da önemini kavrattı̆̆ konusunda beceri geliştirdiğini ifade etmişlerdir.

Yukarıdaki sonuçlar incelendiğinde Türk eğitim tarihi dersinin 21. Yüzyıl becerilerinden olan olan eleştirel düşünme, sorgulama ve sorumluluk bilincinin kazandırılmasında etkili bir ders olduğu görülmüştür. Bu konuda etkili bir sonuca ulaşılması için ülke genelindeki üniversitelerin eğitim fakültelerinde de bu tür çalışmalar yapılması ve bu dersin daha etkili olarak işlenmesi, yeni yöntem ve tekniklerin geliştirilmesi, ders konularında yeniliklerin yapılması, haftalık iki ders saatinin yeterli olup olmadığı konusunda çalışmaların yapılması bu tür çalışmaları tamamlaması açından önerilebilir. 
EXTENDED ABSTRACT

\section{Contribution of History of Turkish Education course to the Development of Critical thinking, Sense of Responsibility, Query skill of the Students in the Faculty of Education (A Sample of Aksaray University) \\ Savaş Karagöz Aksaray University}

Critical thinking, sense of responsibility and query skill development are counted as important features that should be gained at all levels of education. Indeed, the basis of being a modern society producing knowledge lies in educated individuals who make new inventions and discoveries and who have critical and creative thinking skills who want to initiate social change (Orakcl, Durnali, and Aktan, 2019). Critical thinking, especially in courses related to social sciences, is considered to be the "desired outcome" (Watson and Glaser, 1964, p.9). Similarly, in the programs launched by the Ministry of National Education in 2005, the importance of critical thinking, which is one of the eight basic skills under the name of "Basic Skills", is also emphasized. Within this context, the problem of training talented teachers who can meet the requirements of the program continues to confront us. At this point, education faculties play a vital role. Paul, Elder and Bartell (1997) reflect the importance of education faculties by emphasizing the needs of teachers with these skills in order to raise teacher candidates who can think critically and have problem solving skills.

The present study has the aim of examining views, opinions and mentalities of sophomore, junior and senior students on History of Turkish Education in college of education at Aksaray University during the 2018-2019 academic year. To achieve this aim, a qualitative design was employed in the study. The study group of the research consists of 113 students who voluntarily accepted to participate in the research out of the students who took History of Turkish Education course. The data analysis was done using content 
analysis technique. Based on the views, opinions and mentalities of the students about History of Turkish Education course, the themes named "Skill and Awareness Development" (with subthemes "Thinking Skills Development", "Critical Thinking Skill Development", "Multidimensional Thinking Skill Development", "Independent Thinking Skill Development"), "Query Skill Development", and "Sense of Responsibility", "Realizing the value and necessity of education" and "Taking Lessons from the Past to Build the Future".

In line with the themes named "Skill and Awareness Development" with subthemes "Thinking Skills Development", "Critical Thinking Skill Development", "Multidimensional Thinking Skill Development", "Independent Thinking Skill Development", the most frequently expressed opinions of the participants about History of Turkish Education course indicated that this course enabled them to develop their thinking skills.

The second theme reached as a result of the data analysis is that the teacher candidates stated that they realized the value and necessity of education better thanks to History of Turkish Education course. Although it is a rather widespread and even cliché discourse, education is the sine qua non for a society to progress in economic, social and cultural fields. The society group, which should internalize this situation best, is undoubtedly teachers, because based on individual interests and needs, the task of raising new generations in the character required by the society will be on the shoulders of the teachers,. According to opinions of the teacher candidates, History of Turkish Education course was effective in gaining the perception of providing service to the society by internalizing the value and necessity of education. In this regard, based on opinions of the teacher candidates, the extent to which History of Turkish Education course can have critical consequences for teacher candidates for a nation, how important education is for the future, welfare and existence of a society, and how important this course is for a teacher candidate emerged.

Another contribution of History of Turkish Education course from the opinions of teacher candidates is to be aware of the historical developments and to critically evaluate history and draw lessons from it in order to establish a healthy social and economic world today. This finding is, in a sense, a manifestation of the phrase "He who does not know his past cannot make the best of his present and future, for it is from the past that we learn" within the scope 
of this study. The teacher candidates stated that necessary lessons were not taken from the educational developments experienced in the past and that the steps to be taken will not give the desired results unless necessary lessons were taken from the past. Accordingly, the participants epecially as a Turkish citizen and a teacher candidate also said that History of Turkish Education course made it possible for them to be aware of the necessity to take lessons from the past to build the future. They also stated that History of Turkish Education course made it possible for them to have better understanding, questioning and discussing that science guides in every period, and to take lessons from the past instead of just boasting with it.

\section{Kaynakça / References}

Akyüz, Y. (2019) Türk eğitim tarihi (32. Baskı), Ankara: Pegem Yayınları.

Alabaş, R. (2016). Türk eğitim tarihi dersinin önemi hakkında öğretmen adaylarının görüşleri. Cumhuriyet International Journal of Education-CIJE. 5(4),89102.

Arikan, A, Ünver, Ş, Süzer, H . (2007). Yabancı dil eğitimi programlarında türk eğitim tarihi dersinin önemi ve içeriğine ilişkin öğrenci görüşleri. Hacettepe Üniversitesi Ĕ̆gitim Fakültesi Dergisi, 33(33), 24-32.

Burnard, P., Gill, P., Stewart, K., Treasure, E. ve Chadwick, B. (2008). Analysing and presenting qualitative data. British Dental Journal, 204(1), 429-432.

Dinç, E. (2009). Etkili tarih öğretimi. Gazi Üniversitesi Gazi Eğitim Fakültesi Dergisi. 29 (5), 1427-1451.

Dilekli, Y. (2019). What are the dimensions of thinking skills in Turkish literature: a content analysis study?. International Journal of Evaluation and Research in Education (IJERE), 8(1), 110-118 doi: 10.11591/ijere.v8.i1.pp110-118.

Duman, T. (2019). Türkiye'de ortaöğretimde öğretmen yetiştirme (Tarihi Gelişimi), İstanbul: MEB Basımevi.

Erdem, A. R. (2013). Türk eğitim tarihi dersinin öğretmen adaylarının eğitimi açısından önemi, (Ed. M. Aydın), Prof. Dr. Önder Göçgün Armağan Kitabı. Denizli: Pamukkale Üniversitesi Yayınları No: 28, 441-474.

Ergün, M. (2008). Cumhuriyet dönemi eğitim tarihi. Türkiye Araştırmaları Literatür Dergisi, 6(12), 321 -348.

Ersöz, Y. ve Arıbaş, S. (2014). Türk eğitim tarihi dersi öğretiminde farklı bir yaklaşım: resim öğretmenliği öğrencilerinin sergi çalışması, Uluslararası Sosyal Araştırmalar Dergisi, 7(34), 760-767. 
Güçlü, M. (2014). İlköğretim Dergisi'nin fen ve matematik öğretimi açısından değerlendirilmesi (1939-1966), Turkish Studies, 9(7), 311-330.

Güçlü, M. (2016). İlköğretim Dergisinde yayımlanan öğretmenlik mesleği ile ilgili makalelerin değerlendirilmesi (1939-1966), Nevşehir Hacı Bektaş Veli Üniversitesi Sosyal Bilimler Enstitüsü Dergisi, 3(2014), 111-127.

Güçlü, M. ve Bozgeyikli, H. (2016). Öğretmen adaylarının türk eğitim tarihi dersine yönelik tutumlarının incelenmesi, Tarih Okulu Dergisi (TOD), 9(25), 401-415.

Güven, İ. (2018b). Türk eğitim tarihi. Ankara: Pegem yayınları.

Güven, İ. (2019a). Eğitim tarihi. Ankara: Pegem yayınları.

Hobsbawm, E.J. (1997) On History. London: Weidenfeld and Nicholson.

Kamer, S.T. ve Şimşek, A.S. (2016). Türk eğitim tarihi dersine yönelik öğretmen adaylarının tutumlarını ölçülmesi, Ahi Evran Üniversitesi Kırşehir Eğitim Fakültesi Dergisi (KEFAD), 17(2), 663-678.

Köstüklü, N. (2004). İlk ve orta öğretimde tarih öğretimi problemler ve öneriler. Erdem, 14(41), 1-28.

Miles, M.B., ve Huberman, A. M. (1994). Qualitative data analysis: An expanded sourcebook ( $2^{\text {nd }}$ ed.). California: SAGE Publications.

Orakc1, Ş., Durnalı, M., \& Aktan, O. (2019). Fostering critical thinking using instructional strategies in English classes: Fostering critical thinking using instructional strategies in English classes. In S. P. Robinson, \& V. C. Knight (Eds.). Teacher education pedagogy and the importance of critical thinking and conceptualization. Hershey, PA: IGI Global.

Öztürk, C. ve Fındıkçı, İ. (2015) Türk eğitim tarihinin felsefesi, (Ed.).Prof. Dr.Yahya Akyüz'e Armağan / Türk Eğitim Tarihi Araştırmaları, Eğitim ve Kültür Yazıları. Ankara: Pegem Akademi yay.s.663-683.

Paul, R., Elder, L. \& Bartell, T. (1997). California teacher preparation for instruction in critical thinking: Research findings and policy recommendations. The Foundation for Critical Thinking: Dillon Beach, CA.

Sadak, N. (1916). İmi terbiye tarihi. Tedrisat Mecmuast, 6(33-1), 160-165.

Slater, J. (1989). The Politics of History Teaching: A Humanity Dehumanized. (Special Professorial Lecture). London: Institute of Education, University of London.

Taşdemirci, E. (2010). Türk eğitim tarihi. Ankara: Gündüz yayıncllık. 
Tashakkori, A. ve Teddlie, C. (2003). The past and future of mixed methods research: From data tirangulation to mixed method model designs. A. Tashakkori ve C. Teddlie (Editörler), Handbook of mixed methods in social and behavioral research içinde (s. 671-701). CA: Thousand Oaks.

Türer, A. (2016). Türk eğitim tarihi. Ankara: Detay yayınclık.

\section{Kaynakça Bilgisi / Citation Information}

Karagöz, S. (2020). Türk eğitim tarihi dersinin eğitim fakültesi öğrencilerinde eleştirel düşünme, sorgulama ve sorumluluk bilinçlerinin gelişimine katkısı (Aksaray üniversitesi örneği). OPUS-Uluslararası Toplum Araştırmaları Dergisi, 16(27), 210-235. DOI: 10.26466/opus.733260 